\title{
Hermeneutyka prawa kanonicznego przedmiotem rotalnego przemówienia papieża Benedykta XVI w 2012 roku
}

Wygłoszone przez papieża Benedykta XVI już siódme przemówienie do Trybunału Roty Rzymskiej dnia 21 stycznia 2012 roku stało się okazją dla Biskupa Rzymskiego do podjęcia przez niego kilku ważnych zagadnień dotyczących kanonicznego procesu o stwierdzenie nieważności małżeństwa, w szczególności do podjęcia problematyki dotyczącej hermeneutyki prawa kanonicznego ${ }^{1}$. Wspomniana hermeneutyka prawa kanonicznego, mówiąc najogólniej, zajmuje się problemami związanymi ze zrozumieniem oraz interpretacją tekstów prawnych, przede wszystkim $\mathrm{w}$ procesie poznawania prawdy ${ }^{2}$.

Wczytując się w powyższą alokucję rotalną, należałoby wyróżnić następujące jej tematy: (1) kościelny wymiar sprawiedliwości ma służyć zbawieniu dusz (salus animarum), (2) hermeneutyka prawa kanonicznego jest ściśle związana z koncepcją kościelnego prawa, (3) interpretacja prawa Kościoła,

I Zob. Discorso del Santo Padre Benedetto XVI in occasione dell'inaugurazione dell'anno giudiziario del Tribunale della Rota Romana, [w:] http://www.vatican.va/holy_father/benedict_xvi/speeches/2012/january/documents/ (26.01.2012).

2 Zob. A. Bronk, Hermeneutyka, [w:] Encyklopedia katolicka, t. 6, Lublin 1993, kol. 770. 
(4) rola zasad hermeneutycznych dla kanonicznego procesu małżeńskiego oraz (5) nowe kompetencje Trybunału Roty Rzymskiej.

1. Znaczenie posługi tak Trybunału Apostolskiego, jak i całego kościelnego wymiaru sprawiedliwości dla salus animarum Ludu Bożego - tak należałoby określić pierwszy fragment papieskiej alokucji rotalnej z 2012 roku. W kontekście troski o powszechne zbawienie Papież odniósł się do zapowiedzianego „ważnego wydarzenia eklezjalnego”, tj. do „Roku wiary”, którego rozpoczęcie związane jest z pięćdziesiątą rocznicą otwarcia Soboru Watykańskiego II, który rozpoczął się 11 października 1962 roku. Benedykt XVI - przywołując to, co napisał w motu proprio Porta fidei, odniósł się do postanowień Pawła VI, który po raz pierwszy podjął myśl o konieczności takiej refleksji, przede wszystkim świadomy poważnych trudności wynikających z wyznawania wiary oraz jej poprawnej interpretacji. Sukcesywnie Papież zapowiedział, że w swoim przemówieniu pragnie podjąć temat, który związany jest ze służbą Trybunału Apostolskiego Kościołowi i pozostaje jednocześnie ważnym zagadnieniem dla kościelnego wymiaru sprawiedliwości, a którym jest interpretacja prawa kanonicznego w porządku jego aplikacji do konkretnych przypadków, o których mówią kan. $16 \$ 3 \mathrm{KPK}$ oraz kan. $1498 \$ 3 \mathrm{KKKW}^{3}$ : „Związek z tematem powyżej wskazanym - poprawna interpretacja wiary - nie redukuje się z pewnością do asonansu semantycznego, uwzględnia bowiem, że prawo kanoniczne znajduje w prawdach wiary swój fundament oraz swój właściwy sens, oraz że lex agendi nie może nie odzwierciedlać lex credendi. Kwestia interpretacji prawa kanonicznego stanowi zresztą argument wystarczająco szeroki oraz skomplikowany, w związku z czym skupię się jedynie na kilku obserwacjach"4.

3 „Interpretatio autem per modum sententiae iudicialis aut actus administrativi in re peculiari, vim legis non habet et ligat tantum personas atque afficit res pro quibus data est" (CIC, can. $16 \$ 3$ ); „Interpretatio autem per modum sententiae iudicialis aut actus administrativi in re speciali data vim legis non habet et obligat tantum personas atque afficit res, pro quibus data est" (CCEO, can. 1498 \$ 3).

4 Discorso del Santo Padre Benedetto XVI in occasione..., dz. cyt. Problematyka interpretacji prawa kanonicznego została już podjęta w przemówieniach rotalnych, między innymi przez papieża Jana Pawła II po promulgacji nowego Kodeksu prawa kanonicznego w latach 1984 i 1986 (AAS, 1984, vol. 76, s. 643-649; AAS, 1986, vol. 78, s. 921-925). Zob. T. Rozkrut, Jan Pawet II do Roty Rzymskiej, Tarnów 2003, s. 101-112. 
2. Hermeneutyka prawa kanonicznego jest ścisłe powiązana z koncepcją prawa Kościoła. Benedykt XVI wskazał wyraźnie, że ilekroć staramy się identyfikować prawo kanoniczne (il diritto canonico) z systemem ustaw kanonicznych (le leggi canoniche), znajomość tego, co jest jurydyczne w Kościele, musi pozostawać w istotnym związku ze zrozumieniem tego, co zostało postanowione przez teksty prawne. Na pierwszy rzut oka takie ujęcie waloryzowałoby w sposób pełny prawo ludzkie, co jednak ewidentnie prowadziłoby do zubożenia takiej koncepcji, albowiem związane byłoby z pominięciem w praktyce prawa naturalnego oraz prawa Bożego pozytywnego, jak również witalnej relacji każdego prawa ze wspólnotą Kościoła oraz jego misją; w ten sposób także interpretacja jego prawa byłaby pozbawiona życiowego kontaktu z kościelną rzeczywistością.

W ostatnich czasach - zwrócił sukcesywnie uwagę Benedykt XVI - mamy do czynienia z kierunkami, które ostrzegają przed zbyt wielkim przywiązaniem do ustaw kościelnych, poczynając od Kodeksów, oceniając je jako manifestację zbytniego legalizmu. Konsekwentnie zostały zaproponowane rozwiązania hermeneutyczne, które prowadzą do takiej innowacji prawnej, że pojedyncza sytuacja stawałaby się czynnikiem kształtującym autentyczne znaczenie obowiązującej ustawy w konkretnym przypadku. Wśród podstaw dla takiej interpretacji należałoby, zdaniem Papieża, wymienić: miłosierdzie, słuszność oraz oikonomię - tak bardzo drogą tradycji wschodniej. Wypada jednak szybko zaznaczyć, że takie ukazywanie rozumienia prawa nie pokonuje wspomnianego pozytywizmu, który w ten sposób odsłania, że interpretacja staje się zasadnicza w ustaleniu tego, co jest jurydyczne. W takim wypadku brakuje poszukiwanego obiektywnego sensu prawa, co prowadzi w konsekwencji do ryzyka popadnięcia w samowolę, ponadto w ten sposób hermeneutyka prawa zostaje pozbawiona znaczenia, albowiem zanika zatroskanie o poznanie samej dyspozycji prawa: „Zapewne w takich wypadkach mamy do czynienia z odniesieniem do fenomenów witalnych, w których jednak nie występuje wewnętrzny wymiar jurydyczny" - podkreślił Papież.

Istnieje jednak inna droga, na której odpowiednie zrozumienie prawa kanonicznego otwiera drogę do takiej jego interpretacji, która łączy się z poszukiwaniem prawdy oraz sprawiedliwości w Kościele, bowiem słuszne prawo nie może być oddzielone od sprawiedliwości. Wspomniana zasada, na temat której Benedykt XVI mówił podczas swojej wizyty w Parlamencie Federalnym w Berlinie, jest naturalnie obowiązująca także dla prawa kanonicznego, w tym 
sensie, że ono nie może być zawężone jedynie do systemu normatywnego ludzkiego, ale musi być połączone z porządkiem sprawiedliwości Kościoła. W tym znaczeniu możemy mówić o istnieniu hermeneutyki legalnej, która byłaby autentycznie prawna, w tym sensie, że pozostawałaby w syntonii ze znaczeniem własnym prawa, tak aby można było stawiać zasadnicze pytanie na temat tego, co jest sprawiedliwe w każdym wypadku ${ }^{5}$.

Wyodrębniony fragment alokucji wydaje się być niezmiernie ważnym rozważaniem natury doktrynalnej tak dla sukcesywnych wywodów Benedykta XVI, jak i dla poznania zasad, które muszą być uwzględniane przy poprawnej interpretacji istniejącego porządku prawnego w Kościele.

3. Interpretacja prawa w Kościele. W tak ukazanej perspektywie Benedykt XVI zauważył, że wysiłek interpretacyjny, który niekiedy bywa ciężki, nabiera właściwego sensu oraz bezstronności, czyli mówiąc inaczej staje się obiektywny oraz sprawiedliwy. Zastosowanie bowiem środków interpretacyjnych przewidzianych przez Kodeks prawa kanonicznego w kan. 17, zaczynając od słów „według własnego znaczenia słów, rozważanego w tekście i kontekście" nie może być postrzegane jedynie jako ćwiczenie o charakterze logicznym. W tym wypadku mamy bowiem do czynienia z zadaniem, które jest ożywiane poprzez autentyczny kontakt z kompleksową rzeczywistością Kościoła, która pozwala na penetrowanie prawdziwego sensu litery prawa; „W ten sposób potwierdza się także poprzez hermeneutykę prawa to, że autentycznym horyzontem jest ten związany z prawdą prawną, którą należy kochać, szukać oraz jej służyć”.

Wynika z tego, że interpretacja prawa kanonicznego musi mieć miejsce w Kościele, czyli w specyficznym środowisku; w tym wypadku nie mamy bowiem do czynienia z sytuacją zewnętrzną i środowiskową, ale przeciwnie mamy odwołanie do samego humus (gruntu) prawa kanonicznego oraz do rzeczywistości przez nie regulowanej. Zasada „sentire cum Ecclesia” ma znaczenie

5 „Odnośnie tego wypada zaobserwować, że w celu uchwycenia własnego znaczenia prawa należy zawsze spoglądać na rzeczywistość, która jest regulowana, i to nie tylko wtedy, kiedy prawo ma charakter zdecydowanie wyjaśniający prawo Boże, ale także wtedy, kiedy wprowadza w sposób konstytutywny reguły ludzkie. One winny bowiem być interpretowane także w świetle rzeczywistości regulowanej, która zawiera zawsze jądro składające się z prawa naturalnego oraz Bożego pozytywnego, z którym musi pozostawać zawsze w zgodzie każda norma, aby była racjonalną oraz rzeczywiście jurydyczną" (Discorso del Santo Padre Benedetto XVI in occasione..., dz. cyt.). 
także w dyscyplinie, przede wszystkim z powodu fundamentów doktrynalnych, które są zawsze obecne oraz stosowane w normach prawnych Kościoła. W tym sensie jest stosowana także do prawa kanonicznego owa hermeneutyka odnawiania poprzez kontynuację, bowiem dojrzałość chrześcijańska prowadzi zawsze do coraz większego umiłowania prawa oraz do tego, aby je rozumieć oraz wiernie stosować.

Wymieniona postawa winna być stosowana do wszystkich kategorii interpretacji. Poczynając od naukowych poszukiwań w dziedzinie wykładni prawa kanonicznego, poprzez jego konkretną interpretację sądową oraz zastosowanie $\mathrm{w}$ administracji, aż po codzienne poszukiwanie słusznych rozwiązań dotyczących życia wiernych oraz wspólnot. Stąd też konieczny jest wysiłek oraz umiłowanie studiowania tradycji prawnej Kościoła celem identyfikowania się z nią, jak również z dyspozycjami wydanymi przez Pasterzy, w sposób specjalny winno to dotyczyć ustaw papieskich oraz magisterium w kwestiach prawnych, które samo z siebie jest obowiązujące w przedmiocie nauczania na temat prawa ${ }^{6}$.

4. Powyższa refleksja - jak zaznaczył Benedykt XVI - nabiera specjalnego znaczenia w relacji do przepisów, które określają konstytutywny akt małżeństwa, jego konsumację, ważne przyjęcie święceń, oraz do tych, które odnoszą się do właściwych procesów ${ }^{7}$. Tak jednomyślna hermeneutyka, przede wszystkim w tym, co jest istotne, w żaden sposób nie uśmierca funkcji sprawowanej przez trybunały lokalne, które jako pierwsze są powołane, ażeby spotykać się ze skomplikowanymi rzeczywistymi sytuacjami, rodzącymi się w różnych kontekstach kulturowych. Każdy z nich jest zobowiązany do postępowania

6 „Jedynie w ten sposób można zobaczyć przypadki, poprzez które sytuacje konkretne wymagają rozwiązania słusznego w celu osiągnięcia sprawiedliwości, której norma generalna ludzka nie mogła przewidzieć i będzie w stanie manifestować, poprzez ducha wspólnoty, to, co może służyć ulepszeniu aspektu ustawodawczego” (tamże).

7 „Taka właściwa syntonia z prawdziwym znaczeniem prawa Kościoła staje się zagadnieniem dotyczącym szerokiego oraz głębokiego praktycznego wpływu na życie osób oraz wspólnot i wymaga specjalnej uwagi. W szczególności należy także aplikować wszystkie środki wiążące prawnie, które dążą do zapewnienia owej jedności w interpretacji oraz aplikacji praw, a które są wymagane przez sprawiedliwość: magisterium papieskie szczególnie dotyczące tych zagadnień, zawarte przede wszystkim w przemówieniach do Roty Rzymskiej, orzecznictwo Roty Rzymskiej, normy oraz deklaracje wydane przez inne Dykasterie Kurii Rzymskiej” (Discorso del Santo Padre Benedetto XVI in occasione..., dz. cyt.). 
z uwzględnianiem prawdy znajdującej się w prawie, dążąc do przykładnego praktykowania, poprzez aplikację tak sądową, jak i administracyjną, wspólnej dyscypliny, jako istotnego aspektu jedności Kościoła.

5. Na końcu swojego rotalnej alokucji w 2012 roku papież Benedykt XVI odniósł się do obowiązującej od 1 października 2011 roku modyfikacji kompetencji zawartej w motu proprio Quaerit semper z 30 sierpnia 2011 roku, mocą której zostały przeniesione do Trybunału Apostolskiego sprawy związane z postępowaniem dotyczącym dyspensy od małżeństwa zawartego, ale niedopełnionego, jak również sprawy związane z nieważnością święceń ${ }^{8}$.

Podsumowując, należy powiedzieć, że nowością tej alokucji rotalnej jest przede wszystkim zwrócenie uwagi na znaczenie hermeneutyki prawa kanonicznego, a co za tym idzie na konieczność postrzegania norm Kościoła w relacji do niezbywalnego fundamentu, którym jest prawo naturalne oraz Boże pozytywne. Właściwa interpretacja prawa kanonicznego dokonuje się jedynie wewnątrz Kościoła, a sędzia kościelny jest powołany do takiej interpretacji prawa, aby wierni byli opromieniani blaskiem prawdy; stąd też nie może on pozostawać ponad prawem czy też działać wbrew postanowieniom prawa?.

Zestawiając rotalne przemówienie papieża Benedykta XVI z rotalnymi alokucjami papieża Jana Pawła II, zwłaszcza z tymi z lat 1984 oraz 1986, należałoby podkreślić wskazanie w nim jasnych oraz niezastąpionych zasad, które zawsze należy uwzględniać przy interpretacji, tak procesowej, jak i w materii administracyjnej, obowiązujących kościelnych norm prawnych. Część z nich jest zawarta w Kodeksie prawa kanonicznego, natomiast komentowane przemówienie mówi o zasadach hermeneutycznych, które winny być stosowane zarówno przez kościelne sądownictwo, jak i przez kościelne organy administracyjne.

8 Zob. Il saluto del decano. Prevalente stile pastorale, "L'Osservatore Romano", 22 I 2012, s. 8.

9 Zob. Messa del cardinale Bertone nella Capella Paolina, Sapienza e intelligenza al servizio della giustizia, tamże. 